\title{
Response of Wheat (Triticum Aestivum) Cultivars to Different Tillage Practices Grown under Rice-wheat Cropping System
}

\author{
Ali Imran ${ }^{1, *}$, Jamil Shafi ${ }^{2}$, Nadeem Akbar ${ }^{1}$, Waqas Ahmad ${ }^{3}$, Mubasher Ali ${ }^{2}$, Sohail Tariq ${ }^{4}$ \\ ${ }^{1}$ Department of Agronomy, University of Agriculture Faisalabad (38040) Pakistan \\ ${ }^{2}$ Department of Plant Pathology, University of Agriculture, Faisalabad (38040) Pakistan \\ ${ }^{3}$ Institute of Horticultural Sciences, University of Agriculture, Faisalabad (38040) Pakistan \\ ${ }^{4}$ Institute of Agri. Extension and Rural Development, University of Agriculture, Faisalabad (38040) Pakistan \\ *Corresponding Author: uaf3840@gmail.com
}

Copyright (C) 2013 Horizon Research Publishing All rights reserved.

\begin{abstract}
A field experiment was carried out to determine the effect of tillage on growth and yield of two wheat cultivars sown after rice at the Agronomic Research Area, University of Agriculture, and Faisalabad during the winter season 2012-13. The experiment was laid out in Randomized Complete Block Design (RCBD) with split plot arrangement having three replications with a net plot size of $3.0 \mathrm{~m} \times 7.0 \mathrm{~m}$. The experiment comprised of two wheat cultivars with four tillage treatments viz. Zero tillage, reduced tillage (only one cultivation+hand drilling), conventional method (3 cultivation followed by planking thand drilling) and deep ploughing (one deep ploughing with chisel plough and one cultivation followed by planking+hand drilling). Maximum grain yield was obtained in Zero tillage treatment in both cultivars as compared to all other three tillage treatments. Similarly, the spike length number of tillers, number of grains spike ${ }^{-1}, 1000$ - grain weight, biological yield, and harvest index were the highest in Zero tillage. Zero tillage in wheat performed well in the entire crop data parameters and showed effectively high yield in wheat.
\end{abstract}

Keywords Tillage, Zero Tillage, Reduced Tillage, Deep Tillage, Wheat

\section{Introduction}

Wheat (Triticum aestivum L.) belongs to family Poaceae and is very important crop as it contributes major portion of staple food for the world's population. In Pakistan, total cultivated area of wheat is about 9.210 million hectares and the total production is about 24.03 million tons during the year 2011-12. It is involved in contributing 14.4 percent to the value added in agriculture and 3 percent added to the gross domestic production of Pakistan [1]. It is grown mainly under irrigated conditions and its water requirement ranges from 20-21 inches per acre. Wheat is a major source of carbohydrates in human diet. Pakistan is ranking in the top ten highly producing countries of wheat but its production in Pakistan has not exceeded beyond $25-35 \%$ due to shortage of water, changing climates, reduction of land resources of good quality due to increased deforestation and urbanization and decreased investment of public sector in agricultural systems [2].

Wheat production can be improved by using better inputs, proper production technology and by proper tillage practices. Crop yield is affected by these field operations due to their effect on chemical and physical characteristics of soil and water conservation [3]. Important factors like soil tillage and manure application affect soil physical properties and wheat yield. Tillage contributes up to $20 \%$ among all the crop production factors [4]. Use of intensive and unnecessary conventional tillage practices is often harmful to soil. Therefore, currently there is a significant interest and emphasis on the shift to the reduced and zero-tillage for increasing water use efficiency of summer crops, controlling erosion process and increasing crop production [5]. Wheat grown after rice is generally delayed upto 2-3 weeks and every day delay in sowing of wheat after $25^{\text {th }}$ November, the yield reduces about $1 \%$ per day. $[6,7]$.

Zero tillage technology has been adopted to prevent late sowing of wheat. It facilitates sowing of wheat at proper time and good crop establishment. It also saves the cost of water and preparation of seedbed up to 30\% [8]. Zero-tillage technology enhances the wheat yield as compared to the other tillage practices and facilitate less use of machinery and hence energy can be saved through less consumption of fuel [9]. Zero tillage system performed better as compared to other tillage practice because it is very cheap as output obtained from this system is higher than other tillage systems and also this technology is environment-friendly [10]. Deep tillage disrupts high-density soil layers, increases water 
infiltration rate and movement in soil and increases crop productivity [11]. Deep tillage reduces bulk density; compaction effects and enhances nutrient uptake, saturation percentage and saturated hydraulic conductivity resulting in higher yields. Deep tillage destroys plough pan layer and increases productivity of light coloured soils when combined with manure application. [12]. Deep tillage disrupts, inverts and pulverizes sub-surface and minimizes soil penetration resistance [13].

Keeping in view above consideration the objective of this study is to assess the economic potential and associated risks of different tillage systems for two new wheat cultivars under the prevailing conditions of Faisalabad.

\section{Materials and Methods}

A field study was conducted at the Agronomic Research Area, University of Agriculture, Faisalabad in the year 2012-13. In this experiment two newly evolved wheat cultivars, Punjab-2011 and Millet- 2011 were cultivated at four tillage practices like zero, reduced, conventional and deep tillage. Seed rate of $125 \mathrm{~kg} / \mathrm{ha}$ was used and sowing will be done in lines by single row hand drill in the third week of November. The experiment was laid out in split plot arrangement randomizing the tillage practices in main plots and wheat cultivars in sub plots. A recommended dose of fertilize was applied as $125 \mathrm{~kg} / \mathrm{ha}$, Nitrogen and $100 \mathrm{~kg} / \mathrm{hac}$, Phosphorus in the form of Urea and Diammonium phosphate. All other practices was kept normal and uniform for all the treatments.

The experiment was executed in Randomized Complete Block Design with split plot arrangement with three replications having net plot size of $3 \mathrm{~m} \times 7 \mathrm{~m}$. The experiment consists of following treatments.

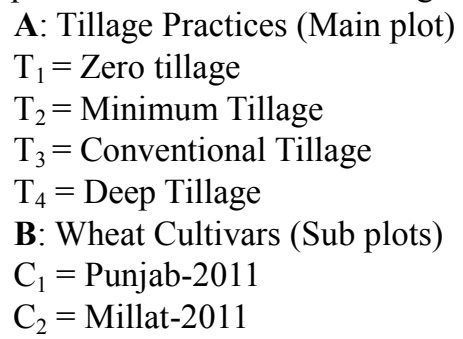

Data on the following observations were collected by using standard procedures;

1) Germination count $\left(\mathrm{m}^{2}\right)$

2) Plant height at harvest $(\mathrm{cm})$

3) Fertile tillers per $\left(\mathrm{m}^{2}\right)$

4) Spike length $(\mathrm{cm})$

5) Number of spikelets per spike

6) Number of grains per spike

7) 1000 grain weight (g)

8) Biological yield $\left(\mathrm{t} \mathrm{ha}^{-1}\right)$

9) Grain yield $\left(t_{h a}^{-1}\right)$

10) Straw yield $\left(\mathrm{t} \mathrm{ha}^{-1}\right)$

11) Harvest index (\%)

12) Economic Analysis

\subsection{Statistical Analysis}

The data so collected was analyzed statistically by using fisher's analysis of variance technique and LSD test at $5 \%$ probability level was applied to compare the difference among the treatment means [14].

\section{Results}

\subsection{Germination Counts Per Unit Area $\left(\mathbf{M}^{2}\right)$}

Better germination resulted in good crop establishment which ultimately accounts much for higher yield, because of the optimum plant population. Interaction of cultivars and tillage revealed that Zero tillage performed best in cultivar Punjab-2011. Higher germination $\left(207.5 \mathrm{~m}^{2}\right)$ was achieved in Zero tillage and lower germination $\left(182.59 \mathrm{~m}^{2}\right)$ was obtained in conventional tillage in cultivar Millat-2011. Other tillage practices indicated results in between the Zero and Conventional tillage practices (Table.1). Among all the tillage practices Zero tillage performed best then deep and reduced tillage and conventional tillage showed poor results. This may be due to higher amount of moisture retention and organic matter in the soil in Zero tillage practice which has directly affected the germination count of wheat cultivars.

\subsection{Plant Height at Harvest (cm)}

Plant growth is counted in terms of plant height which is highly affected by crop nutrition and the environmental situations. Comparison of treatment means (Table. 1) showed that among wheat cultivars Punjab-2011 achieved the maximum plant height $(98.94 \mathrm{~cm})$ as compared to Millat-2011 $(95.14 \mathrm{~cm})$. Among all tillage practices Zero tillage gave maximum plant height $(103.48 \mathrm{~cm})$ as compared to other tillage practices. Results of reduced tillage and deep tillage were similar. These were next to give high plant height of $96.38 \mathrm{~cm}$ and $95.40 \mathrm{~cm}$ respectively. Both these were statistically at par with each other. At conventional tillage both cultivars achieved the lowest plant height i.e. $92.91 \mathrm{~cm}$ as shown (Table.1). This may be due to higher organic matter contents in Zero tillage which has directly affected the vegetative growth of wheat.

\subsection{Fertile Tillers $\left(\mathrm{m}^{2}\right)$}

Fertile tiller production is an important yield determining parameter in wheat. more the number of fertile tillers more the grain yield of wheat. Comparison of treatment means (Table 1) indicated that among these two cultivars Punjab-11 produce more number of fertile tillers (419.33) than the Millat-11 (405.58). Among tillage practices Zero tillage maximum number of productive tillers (418.83) was recorded. Deep tillage was next to produce highest number of fertile tillers (414.67). The minimum number of productive tillers (405.33) was produced in conventional 
tillage practice. Zero tillage and Deep tillage were statistically at par with each other and minimum tillage and Conventional tillage were statistically at par with each other giving almost similar results. The interaction between cultivars and tillage practices was also significant. Highest number of fertile tillers (429.66) were counted in Punjab-11 at Zero tillage and lowest tillers (399.66) were counted in Millat-11 at Conventional tillage (Table.1).

\subsection{Spike length (cm)}

Spike length is a key factor contributing towards the yield of wheat. Higher the length of the spike higher would be the gains production per spike leading to higher yield. Comparison of treatment means (Table 1) indicated that the cultivar Punjab-11 achieved maximum spike length of $(11.143 \mathrm{~cm})$ and minimum spike length $(10.454 \mathrm{~cm})$ was measured in Millat-11. Non-significant difference was shown in different tillage practices. Among tillage practices maximum spike length $(11.158 \mathrm{~cm})$ was measured in Zero tillage. Deep tillage $(10.90 \mathrm{~cm})$ and Conventional tillage $(10.67 \mathrm{~cm})$ were next to show maximum spike length. Zero tillage, deep tillage and Conventional tillage were statistically at par with each other. While minimum spike length $(10.46 \mathrm{~cm})$ was observed in reduced tillage..

Table 1. Response of different morphological attributes of wheat to different tillage practices

\begin{tabular}{|c|c|c|c|c|c|c|}
\hline & & $\begin{array}{c}\text { Zero } \\
\text { Tillage }\end{array}$ & $\begin{array}{c}\text { Reduced } \\
\text { Tillage }\end{array}$ & $\begin{array}{c}\text { Conventional } \\
\text { Tillage }\end{array}$ & $\begin{array}{l}\text { Deep } \\
\text { tillage }\end{array}$ & Means \\
\hline $\begin{array}{c}\text { Germination Count } \\
\left(\mathrm{m}^{2}\right)\end{array}$ & $\begin{array}{c}\text { Punjab-11 } \\
\text { Millat-11 } \\
\text { Means }\end{array}$ & $\begin{array}{l}207.50 \\
192.00 \\
199.75\end{array}$ & $\begin{array}{c}198.16 \\
190.83 \\
194.5\end{array}$ & $\begin{array}{l}192.58 \\
182.59 \\
187.59\end{array}$ & $\begin{array}{l}200.47 \\
193.64 \\
197.06\end{array}$ & $\begin{array}{l}199.68 \\
189.77\end{array}$ \\
\hline $\begin{array}{l}\text { Plant Height at Harvest } \\
\qquad(\mathrm{cm})\end{array}$ & $\begin{array}{c}\text { Punjab-11 } \\
\text { Millat-11 } \\
\text { Means }\end{array}$ & $\begin{array}{l}106.93 \\
100.03 \\
103.48\end{array}$ & $\begin{array}{l}98.26 \\
94.50 \\
96.38\end{array}$ & $\begin{array}{l}93.30 \\
92.53 \\
92.91\end{array}$ & $\begin{array}{l}97.31 \\
93.50 \\
95.40\end{array}$ & $\begin{array}{l}98.94 \\
95.14\end{array}$ \\
\hline Fertile tillers $\left(\mathrm{m}^{2}\right)$ & $\begin{array}{c}\text { Punjab-11 } \\
\text { Millat-11 } \\
\text { Means }\end{array}$ & $\begin{array}{l}429.68 \\
408.00 \\
418.83\end{array}$ & $\begin{array}{l}417.00 \\
405.00 \\
411.00\end{array}$ & $\begin{array}{l}411.00 \\
399.66 \\
405.33\end{array}$ & $\begin{array}{l}419.66 \\
409.66 \\
414.67\end{array}$ & $\begin{array}{l}419.33 \\
405.58\end{array}$ \\
\hline Spike length (cm) & $\begin{array}{c}\text { Punjab-11 } \\
\text { Millat-11 } \\
\text { Means }\end{array}$ & $\begin{array}{l}11.80 \\
10.51 \\
11.15\end{array}$ & $\begin{array}{l}10.79 \\
10.13 \\
10.46\end{array}$ & $\begin{array}{l}10.93 \\
10.40 \\
10.67\end{array}$ & $\begin{array}{l}11.03 \\
10.76 \\
10.90\end{array}$ & $\begin{array}{l}11.14 \\
10.45\end{array}$ \\
\hline $\begin{array}{l}\text { No. of spikelets per } \\
\text { spike }\end{array}$ & $\begin{array}{c}\text { Punjab-11 } \\
\text { Millat-11 } \\
\text { Means }\end{array}$ & $\begin{array}{l}18.67 \\
16.29 \\
17.48\end{array}$ & $\begin{array}{l}17.89 \\
16.74 \\
17.32\end{array}$ & $\begin{array}{l}17.90 \\
16.74 \\
17.31\end{array}$ & $\begin{array}{l}17.86 \\
16.58 \\
17.22\end{array}$ & $\begin{array}{l}18.08 \\
16.58\end{array}$ \\
\hline No. of grains per spike & $\begin{array}{c}\text { Punjab-11 } \\
\text { Millat-11 } \\
\text { Means }\end{array}$ & $\begin{array}{l}55.10 \\
50.73 \\
52.92\end{array}$ & $\begin{array}{l}52.25 \\
50.56 \\
51.41\end{array}$ & $\begin{array}{l}51.03 \\
49.98 \\
50.50\end{array}$ & $\begin{array}{l}53.94 \\
52.04 \\
52.99\end{array}$ & $\begin{array}{l}53.08 \\
50.83\end{array}$ \\
\hline 1000-grain weight (g) & $\begin{array}{c}\text { Punjab-11 } \\
\text { Millat-11 } \\
\text { Means }\end{array}$ & $\begin{array}{l}51.23 \\
49.45 \\
50.34\end{array}$ & $\begin{array}{l}47.79 \\
45.85 \\
46.82\end{array}$ & $\begin{array}{l}45.73 \\
43.18 \\
44.45\end{array}$ & $\begin{array}{l}47.93 \\
46.04 \\
46.99\end{array}$ & $\begin{array}{l}48.17 \\
46.13\end{array}$ \\
\hline $\begin{array}{c}\text { Biological Yield (t } \\
\mathrm{ha}^{-1} \text { ) }\end{array}$ & $\begin{array}{c}\text { Punjab-11 } \\
\text { Millat-11 } \\
\text { Means }\end{array}$ & $\begin{array}{l}19.33 \\
17.00 \\
18.16\end{array}$ & $\begin{array}{l}17.16 \\
16.00 \\
16.58\end{array}$ & $\begin{array}{l}17.16 \\
16.66 \\
16.91\end{array}$ & $\begin{array}{l}17.33 \\
16.33 \\
16.83\end{array}$ & $\begin{array}{l}17.75 \\
16.50\end{array}$ \\
\hline Grain Yield $\left(\mathrm{t} \mathrm{ha}^{-1}\right)$ & $\begin{array}{c}\text { Punjab-11 } \\
\text { Millat-11 } \\
\text { Means }\end{array}$ & $\begin{array}{l}5.20 \\
4.54 \\
4.87\end{array}$ & $\begin{array}{l}4.70 \\
4.24 \\
4.47\end{array}$ & $\begin{array}{l}4.76 \\
4.30 \\
4.53\end{array}$ & $\begin{array}{l}4.71 \\
4.26 \\
4.48\end{array}$ & $\begin{array}{l}4.84 \\
4.34\end{array}$ \\
\hline Straw Yield $\left(\mathrm{t} \mathrm{ha}^{-1}\right)$ & $\begin{array}{l}\text { Punjab-11 } \\
\text { Millat-11 } \\
\text { Means }\end{array}$ & $\begin{array}{l}14.13 \\
12.45 \\
13.29\end{array}$ & $\begin{array}{l}12.46 \\
11.75 \\
12.10\end{array}$ & $\begin{array}{l}12.40 \\
12.36 \\
12.38\end{array}$ & $\begin{array}{l}12.62 \\
12.06 \\
12.34\end{array}$ & $\begin{array}{l}12.90 \\
12.15\end{array}$ \\
\hline Harvest Index (\%) & $\begin{array}{c}\text { Punjab-11 } \\
\text { Millat-11 } \\
\text { Means }\end{array}$ & $\begin{array}{l}26.91 \\
26.77 \\
26.84 \\
\end{array}$ & $\begin{array}{l}27.44 \\
26.62 \\
27.03 \\
\end{array}$ & $\begin{array}{l}27.78 \\
26.13 \\
26.80\end{array}$ & $\begin{array}{l}27.19 \\
26.82 \\
26.66\end{array}$ & $\begin{array}{l}27.33 \\
26.33\end{array}$ \\
\hline
\end{tabular}




\subsection{Number of Spikelets per Spike}

The number of spike let pre spike is also a key factor which determines the ultimate grain and straw yield of wheat. Comparison of treatment means (Table 1) indicated the non-significant difference among tillage practices in producing the number of spikelets per spike. The reason behind is the similar handling of all tillage treatments in term of environment and nutrients. In Punjab-11 maximum number of spikelets (18.082) was recorded and the minimum number of spikelets (16.588) was observed in the Millat-11 as shown in table 1 . The reason for the less number of spikelets per spike in Millat-11 was its small spike length .The small spike thus beared small number of spikelets. The interaction was also significant. Punjab-11 achieved maximum number of spikelets per spike (18.67) with Zero tillage while minimum number of spiklets (16.29) were achieved in Millat-11 with Zero tillage.

\subsection{Number of Grains per Spike}

Number of grains per spike is one of the most crucial yield determining component and has directly related to the grain yield of wheat. Punjab-11 gave maximum number of grains per spike (53.083) and Millat-11 gave minimum number of grains per spike (50.831). Among tillage practices deep tillage (52.99) produced highest number of grains per spike over other three tillage practices. Zero tillage (52.92) and Deep tillage were statistically at par with each other and conventional tillage (50.50) and reduced tillage (51.41) were statistically at par with each other (Table 1). The interaction of cultivars and tillage was non-significant

\subsection{0 - Grain Weight (g)}

The weight of grain is a key factor in determining yield and makes larger contributions towards grain yield of wheat. The maximum grain weight was recorded in Zero tillage $(50.34 \mathrm{~g})$ and minimum grain weight $(44.45 \mathrm{~g})$ was recorded in Conventional tillage. Deep tillage (46.99 g) and reduced tillage (46.82) were statistically at par with each other giving almost similar results. Among cultivars significant difference is observed. Punjab-11 gained maximum grain weight (48.173 g) than Millat-11 (46.132 g) (Table. 1). The interaction effect for 1000- grain weight was non-significant.

\subsection{Biological Yield $\left(\mathrm{t} \mathrm{ha}^{-1}\right)$}

Total biological yield indicates overall growth performance of the plant. Comparison of treatment means (Table 1) indicated that biological yield per hectare was maximum in Punjab-11(17.75 $\left.\mathrm{t} \mathrm{ha}^{-1}\right)$ than that of the Millat-11 $\left(16.50 \mathrm{t} \mathrm{ha}^{-1}\right)$. Significant difference was observed between the tillage practices in both cultivars. The highest biological yield was obtained at Zero tillage $\left(18.167 \mathrm{t} \mathrm{ha}^{-1}\right)$ than other tillage practices. The reason was effective utilization of the nutrients by plants under the Zero tillage than that of other tillage practices. While deep tillage (16.83 t $\left.\mathrm{ha}^{-1}\right)$, conventional tillage $\left(16.91 \mathrm{tha}^{-1}\right)$ and reduced tillage $\left(16.58 \mathrm{t} \mathrm{ha}^{-1}\right)$ practices were statistically at par with each other. These observations are related with Maqsood (1998) who conducted an experiment to show the effect of different tillage system on wheat crop (Triticum aestivum L.) and concluded that highest biological yield was found in Zero tillage treatment. This is because of highest plant height and highest spike length in Zero tillage treatment. The interaction was non-significant.

\subsection{Grain Yield $\left(\mathrm{t} \mathrm{ha}^{-1}\right)$}

The final grain yield per unit area is calculated by the combined effects of several yield components which are in turn influenced differentially by the growing situations and crop management strategies. Comparison of treatment means (Table 1) indicated that among cultivars, Punjab-11 achieved higher grain yield (4.84 tha $\mathrm{th}^{-1}$ ) Millat-11 (4.34 $\left.\mathrm{t} \mathrm{ha}^{-1}\right)$ while among tillage practices Zero tillage practice exhibited highest grain yield $\left(4.87 \mathrm{t} \mathrm{ha}^{-1}\right)$ as compared to other three tillage practices. These tillage practices including conventional tillage $\left(4.53 \mathrm{tha}^{-1}\right)$, deep tillage $\left(4.48 \mathrm{tha}^{-1}\right)$ and reduced tillage $\left(4.47 \mathrm{tha}^{-1}\right)$ were statistically at par with each other. Results indicated that wheat yield across the years range from $1790 \mathrm{~kg} \mathrm{ha}^{-1}$ to $2500 \mathrm{~kg} \mathrm{ha}^{-1}$, but there were no significant difference in grain yield among tillage practices in any year or when analyzed across the year. The reason for the higher grain yield in Zero tillage practice may be higher 1000 - grain weight and higher number of grains per spike in Zero tillage treatment. There was significant difference between cultivars as shown in Table 1. The interaction among tillage and cultivars was found to be non-significant.

\subsection{Straw Yield $\left(\mathrm{t} \mathrm{ha}^{-1}\right)$}

Straw yield indicate the potential of a crop to accumulate dry matter in its vegetative parts and it is due to the combined effects of all growth parameters like tillers per area and the final plant height. The data reveals that significant difference was measured between two cultivars. Highest straw yield $\left(12.90 \mathrm{t} \mathrm{ha}^{-1}\right)$ was achieved by Punjab-11 than Millat-11 (12.49 $\left.\mathrm{t} \mathrm{ha}^{-1}\right)$ (Table.1). Among tillage practices also non-significant difference occurred. All the four tillage practices are statistically at par with each other. Interaction was also non-significant.

\subsection{Harvest Index (\%)}

The physiological efficiency of crop plants to convert the photosynthates into grain yield is measured in the form of harvest index. Harvest index mainly depends on the genetic potential of a cultivar and is influenced by different agronomic parameters. The data on harvest index is presented in table1. Punjab-11 achieved maximum harvest index (27.33) than Millat-11 (26.33). All the four tillage practices were statistically at par with each other (Table 1 ). 
Table 2. Economic analysis for Punjab-11 and Millat-11

\begin{tabular}{|c|c|c|c|c|c|}
\hline & & Zero Tillage & Reduced Tillage & $\begin{array}{c}\text { Conventional } \\
\text { Tillage }\end{array}$ & Deep Tillage \\
\hline $\begin{array}{l}\text { Total income } \\
\left(\text { Rs. ha }{ }^{-1}\right)\end{array}$ & $\begin{array}{l}\text { Punjab-11 } \\
\text { Millat-11 }\end{array}$ & $\begin{array}{l}268475 \\
235250\end{array}$ & $\begin{array}{l}240325 \\
220625\end{array}$ & $\begin{array}{l}241750 \\
227075\end{array}$ & $\begin{array}{c}241837.50 \\
223575\end{array}$ \\
\hline $\begin{array}{l}\text { Total cultivation cost } \\
\text { that vary }\left(\text { Rs. } \text { ha }^{-1}\right)\end{array}$ & $\begin{array}{l}\text { Punjab-11 } \\
\text { Millat-11 }\end{array}$ & $\begin{array}{c}97276.1 \\
94440.16\end{array}$ & $\begin{array}{l}97377.66 \\
95401.1\end{array}$ & $\begin{array}{l}102888.47 \\
100908.91\end{array}$ & $\begin{array}{c}101715.47 \\
99737.03\end{array}$ \\
\hline $\begin{array}{l}\text { Net income } \\
\left(\text { Rs. } \text { ha }^{-1}\right)\end{array}$ & $\begin{array}{l}\text { Punjab-11 } \\
\text { Millat-11 }\end{array}$ & $\begin{array}{l}171198.90 \\
140809.84\end{array}$ & $\begin{array}{l}142947.34 \\
125223.90\end{array}$ & $\begin{array}{c}138861.53 \\
126166\end{array}$ & $\begin{array}{l}140122.03 \\
123837.91\end{array}$ \\
\hline BCR & $\begin{array}{l}\text { Punjab-11 } \\
\text { Millat-11 }\end{array}$ & $\begin{array}{l}2.75 \\
2.49\end{array}$ & $\begin{array}{l}2.46 \\
2.31\end{array}$ & $\begin{array}{l}2.34 \\
2.25\end{array}$ & $\begin{array}{l}2.37 \\
2.24\end{array}$ \\
\hline
\end{tabular}

\subsection{Economic Analysis}

The economic analysis of any agronomic practice is necessary from farmer's point of view, as they are often interested in benefits and cost of a certain system and also like to know about risks of adopting new practices. If the benefit cost ratio workout is less than 1, then the present worth of the costs at this discount rate would have exceeded the present worth of the benefit and we would not have recovered our initial expenditure plus the return on our investment from the farm practice.

The data in table 2 indicates a maximum benefit cost ratio under the Zero tillage practice in both wheat cultivars. This can be supported Zero tillage practice to be adopted in ricewheat cropping system for maximum benefit cost ratio. Table 2 and 13 presents that the maximum cost benefit ratio is obtained in Zero tillage practice in both wheat cultivars. Comparing the cultivars, Punjab-11 gave better results (high benefit cost ratio) in Zero tillage than Millat-11. In both cultivars Reduced tillage gave better results (high benefit cost ratio) after Zero tillage then Deep tillage and Conventional tillage respectively. This may be due to higher grain and straw yield in Zero tillage practice table 2 .

\section{Discussion}

Among all the tillage practices Zero tillage performed best then deep and reduced tillage and conventional tillage showed poor results. This may be due to higher amount of moisture retention and organic matter in the soil in Zero tillage practice which has directly affected the germination count of wheat cultivars. These results are in accordance with the finding of Gangwar [15] who study the effect of tillage practices on crop growth, yield and nutrient use in wheat (Triticum aestivum L.) planted after rice (Oryza sativa L.). In Zero tillage maximum number of plant density was observed as compared to other tillage practices. The interaction between the wheat cultivars and tillage practices was significant. While Alvarez [16] conducted an experiment to study effects of tillage practices on wheat crop yield and three tillage practices conventional, reduced and no-tillage were used and it was revealed that in no tillage and reduced tillage wheat germination was lower than conventional tillage.

Maqsood [17, 18] who working on different tillage systems demonstrated that Zero tillage gave maximum plant height. The interaction between the tillage practices and wheat cultivars was non- significant because the plant height is a genetic character and fertilizer application to four tillage systems and two cultivars was uniform according to the recommendation.

Highest number of fertile tillers (429.66) were counted in Punjab-11 at Zero tillage and lowest tillers (399.66) were counted in Millat-11 at Conventional tillage. Su [19] also conducted a field work on winter wheat (Triticum durum L.) to show the influence of conservation tillage on soil water conservation, crop yield, and water-use efficiency. The experiment was conducted using minimum tillage (MT), no tillage with mulching (NT), subsoil tillage with mulching (ST), and conventional tillage (CT). It was shown that the average winter wheat production over 6 years on NT or ST plots were significantly high than that in CT or MT plots. It was because of more number of fertile tillers in Zero tillage. Conventional tillage and minimum tillage yields did not vary significantly between them.

Non-significant difference was shown in different tillage practices. These observations are in accordance with those of Hemmat and Eskandri [20] who showed a non-significant difference in spike length among different tillage systems. Similarly Vita [21] showed the effects of No tillage and Conventional tillage on wheat (Triticum durum L.) and it was investigated that No tillage performed best than Conventional Tillage. The superior effect of No tillage in comparison to Conventional tillage, was due to highest spike length in no tillage than in conventional tillage. Aslam [21, 22] they performed many experiments on tillage practices and confirmed that tillage does not effect on number of spikelet per spike. In present study Conventional tillage practice minimum number of grains was observed. These results are in line with Maqsood [17] who performed experiment to study the effect of tillage on wheat and revealed that Zero tillage gave highest number of grains per 
spike. Singh [23] comparing Zero tillage and conventional tillage indicated that Zero tillage gave maximum number of grains per spike than conventional tillage.

Carr [24] who working on conservation tillage recorded more grain weight in Zero tillage than other tillage practices. Hemmat and skandri, Zamir [20,18]also revealed that test weight or 1000- grain weight was greatly influenced by tillage practices and highest grain weight wad obtained in Zero tillage as compared to other tillage treatments and these results are in accordance to this study. Aslam [24], Izaurralde [25] and Pan [26] who declared that Zero tillage practice increased yield of wheat by $37 \%$ over conventional tillage. However the these findings are contradictory to those of Iqbal [27] and Knowles [28] who reported higher grain yield in sowing of wheat by conventional tillage over Zero tillage. Similarly Janosky [29] analyzed the economics of three tillage practices for wheat. Tillage practices include conventional tillage, reduced tillage and delayed reduced tillage (herbicide and delayed tillage). Results indicated that wheat yield across the years range from $1790 \mathrm{~kg} \mathrm{ha}^{-1}$ to 2500 $\mathrm{kg} \mathrm{ha}^{-1}$, but there were no significant difference in grain yield among tillage practices in any year or when analyzed across the year. The reason for the higher grain yield in Zero tillage practice may be higher 1000- grain weight and higher number of grains per spike in Zero tillage treatment. There was significant difference between cultivars as shown in figure 4.9. All the four tillage practices with respect to Harvest index were statistically at par with each other. These values of harvest index were in line with those of Ahmad [30] and Rasheed [31].

Comparing the cultivars, Punjab-11 gave better results (high benefit cost ratio) in Zero tillage than Millat-11. In both cultivars Reduced tillage gave better results (high benefit cost ratio) after Zero tillage then Deep tillage and Conventional tillage respectively. This may be due to higher grain and straw yield in Zero tillage practice. These results are similar to those of Chhokar [32] who indicated that the reduced expenditure on tillage practices and maximum yield provided additional profit of about Rs. $9516 \mathrm{ha}^{-1}$ for ZT over other tillage practices (conventional and Deep tillage). Thus considering the benefit of $\mathrm{ZT}$ in minimizing the cost and time of cultivation, Zero tillage is a successful practice in rice- wheat cropping system.

\section{Conclusion}

The economic analysis indicates the advantage of Zero tillage over other three tillage practices resulting in maximum returns and profit as compared to other practices by minimizing the cultivation cost. The results achieved ensured the validity of Zero tillage technology which had been proposed for energy conservation with the assurance of satisfactory yield production in Rice- wheat cropping system.

\section{REFERENCES}

[1] GOP, Economic survey of Pakistan. Finance and Economic Affairs Division, Islamabad, 2012.

[2] G. Sarwar, Q. Nawaz. Studies on the efficacy of different post emergence herbicides for the control of weeds and their effect on yield of wheat. Sarhad Journal of Agriculture, Vol.1, 251-259, 1985.

[3] D.J. Bonfil, I. Mufradi, S. Klitman, S. Asido, Wheat grain yield and soil arofile water distribution in a no till arid environment Agronomy Journal, Vol, 91, 368-373, 1999.

[4] N. Ahmad, M. Rashid, A.G. Vaes, Fertilizer and their use in Pakistan, NFDC. Publication, No. 4/96, 2nd Ed, Islamabad. 1996.

[5] M.I. Dawelbeit, E.A. Babiker, Effect of tillage and sowing method on growth and yield of wheat, Soil and Tillage Research, Vol.42, 127-32, 1997.

[6] Randhawa, A.S., R.S. Jolly, S.S. Dhillon. Effect of seed rate and row spacing on the yield of dwarf wheat under different sowing dates. Field Crop Abstracts. Vol.32, 87-96, 1979.

[7] P.R. Hobbs, C. Mann, L. Butler, A Perspective on Research Needs for the Rice-Wheat Rotation, In Klatt, A.R. (ed) Wheat Production Constraints in Tropical Environments, Mexico, CIMMYT, 1988.

[8] M. Aslam, A. Majid M.A. Gill, Zero tillage wheat production technology prospects and threats, Science and Technology Development International Journal, Vol.1, 15-19, 1999.

[9] R.S. Grey, J.S. Taylor, W.J. Brown, Economic factors contributing to the adoption of reduced tillage technologies in central Saskatchewan, Canadian Journal of Plant Sciences, Vol. 76, 661-668. 1996.

[10] S. Nagarajan, A. Singh, R. Singh, S. Singh. Impact Evaluation of zero-Tillage in Wheat Through Farmer's Participatory mode. Paper for international workshop on herbicide resistance management \& Zero tillage in rice-wheat cropping system, Department of Agronomy, CCS Haryana Agricultural University, 2002.

[11] A.T.P. Bennie, F.J.P. Botha, Effect of deep tillage and controlled traffic on root growth, water use efficiency and yield of irrigated maiz and wheat, Soil and Tillage Research, Vol. 7, 85-95. 1986.

[12] S. Higashida, M. Yamagami, Effects of deep ploughing with concomitant application of farm manure on the productivity of arable crops, Bulletin of Hokkaido-Prefectural Agricultural Experiment Stations, Vol.84: 55-64. 2003.

[13] M. K. Khattak, A.Q. Mughal, M.J. Khan, S.B. Bukhari, G.D. Khan. Effect of various tillage practices on selected physical properties in clay loam soil under wheat-maize rotation. Sarhad Journal of Agriculture, Vol.20, 233-241, 2004.

[14] R. G. D. Steel, J.H. Torrie, D.A. Dicky. Principles and procedures of statistics, A Biometrical Approach. 3rd Ed. McGraw Hill, Inc. Book Co. N.Y. (U.S.A.)., 1997.

[15] K.S. Gangwar, K.K. Singh, S.K. Sharma, Effect of tillage on growth, yield and nutrient uptake in wheat after rice in the Indo-Gangetic Plains of India, Journal of Agricultural Science. Vol. 142, 453-459. 2004. 
[16] M. Alvarez, H.S. Steinbach, A review of the effects of tillage systems on some soil physical properties, water content, nitrate availability and crops yield in the Argentine Pampas, Soil and Tillage Research, Vol. 99, 208-212, 2009.

[17] M. Maqsood, Growth and yield of rice and wheat as influenced by different planting methods and nitrogen levels in rice wheat cropping system. Ph.D. Agri. Thesis, Agronomy Department University Agriculture Faisalabad,1998.

[18] M. S. I. Zamir. Agro-Economic studies on different Rice-based cropping system at conventional and zero tillage. Ph.D. Agri. Thesis, Agronomy Department University of Agriculture, Faisalabad, 2006.

[19] Z. Su, J. Shang, W.W. Chi, D. Lv, J. Jiang, G. Huang, J. Gao, R. Hartman, D. Gabriels. Effect of conservation tillage practices on winter wheat water use efficiency and crop yield on the loess plateau, China Agriculture and Water Management, Vol.87, 307-314,2007.

[20] A. Hemmat, I. Eskandri, Dryland winter wheat response to conservation tillage in a continuous cropping system in the northwestern Iran, Soil and Tillage Research, Vol. 86, 99-109. 2004.

[21] P. D. Vita, E.D. Paolo, G. Fecondo, N.D. Fonzo, M. Pisante. No-tillage and conventional tillage effects on durum wheat yield, grain quality and soil moisture content in southern Italy. Soil and Tillage Research, Vol.92, 69-78, 2006.

[22] A. Majid, M. Aslam, P.R. Hobbs, N.I. Hashmi. Results of wheat agronomic research in the Punjab rice wheat area, NARC. Islamabad, Field crop Abstracts. Vol.41, 88-93, 1986.

[23] S. Singh, S.N. Sharma, R. Parsad, S. Singh. The effect of seeding and tillage methods on productivity of rice- wheat cropping system. Soil and Tillage Research. Vol.61, 125-131, 2001.

[24] M. Aslam, A. Majid, N.I. Hashmi, P.R. Hobbs. Improving wheat in the rice wheat cropping system of the Punjab through zero tillage. Pakistan Journal of Agricultural Research, Vol. 14, 8-11. 1993.

[25] P.M. Carr, R.D. Horsley, W.W. Poland. Tillage and seeding rate effects on wheat cultivars, Crop Science, Vol. 43, 202-209. 2003.

[26] R. C. Izaurralde, J.A. Hobbs, C.W. Swallow. Effects of Reduced Tillage Practices on Continuous Wheat Production and on Soil Properties, Agronomy Journal, Vol.78, 787-791, 1986.

[27] M. Iqbal, A. Hassan, A. Ali, M. Rizwanullah. 2005. Residual effect of tillage and farm manure on some soil Physical Properties and Growth of Wheat (Triticum aestivum L.), International Journal of Agricultural Biology, Vol.7, 54-57, 2005.

[28] T. C. B. Knowles, W. Hipp, P.S. Graff, D.S. Marshall. 1993. Nitrogen nutrition of rainfed winter wheat in tilled and no tilled sorghum and wheat residues. Agronomy Journal, Vol.85, 886-893, 1993.

[29] J. S. Janosky, D.L. Young, W.F. Schillinger. Economics of convervation tillage in a wheat fallow system. Agronomy Journal, Vol.94, 527-531, 2002.

[30] M. Ahmad, Problems, Opportunities and prospects of dryland Agriculture in Pakistan. Keynote address in Internatioal seminar on dryland Agriculture in Pakistan, Fauji Fertilizer Company Limited, Pakistan. 1991.

[31] A. Rasheed. Bio-economic efficiency of diverse cotton based inter cropping system at different geometric configuration. M.Sc. (Hons) Agri. Thesis, Univesity of Agriculture Faisalabad, 1992.

[32] R.S. Chhokar, R.K. Sharma, G.R. Jat, A.K. Pundir, M.K. Gathala, Effect of tillage and herbicide on weeds and productivity of wheat under rice-wheat growing system, Pakistan Journal of Agricultural Research, Vol. 19, 21-27, 2007.. 